\title{
2006-1392: ASSESSING THE IMPACT OF CRITICAL THINKING INSTRUCTION UPON THE PREPARATION OF FRESHMAN STUDENTS TO PURSUE ADVANCED DEGREES IN ENGINEERING
}

\section{Annette Donawa, Morgan State University/CAMRA}

Annette Mallory Donawa is currently working on her Ph.D. in Higher Education and Administration at Morgan State University. Within the NASA-sponsored Center of Advanced Microwave Research and Applications (CAMRA), she assists the Director, Dr. Carl White, with strategic planning, in addition to staff and project management.

Her engineering education research is focused on assessing the impact of teaching critical thinking to African American engineering students. The goal is to prepare and motivate minority students to pursue advanced degrees in science, technology, engineering and mathematics (STEM) disciplines.

Ms. Mallory Donawa has more than 20 years of experience in industry, government and academic organizations. Upon degree completion, her goal is to create a Critical Thinking Institute.

\section{Clifton Martin, Morgan State University}

\section{Carl White, Morgan State University}

Dr. Carl White, Professor, has been teaching at Morgan State University for 18 years in the Electrical Engineering Department. He is the Director of CAMRA, and has directed the PACE program for the past 17 years. 


\title{
ASSESSING THE IMPACT OF CRITICAL THINKING INSTRUCTION UPON THE PREPARATION OF Freshman StUdents to Pursue Advanced Degrees in Engineering
}

\begin{abstract}
For more than three decades, programs to accelerate the entry of African Americans and other underrepresented minorities into doctoral programs have been designed and launched. However, evaluation research from these efforts documents varying degrees of success. This variability in outcomes is directly related to the breadth and depth of the variables that contour and shape minority students' performance throughout the academic pipeline.

Over recent years, interventions to increase minority achievement in science, technology, engineering and mathematics (STEM) have been addressed by seeking to intermediate a fairly constant set of variables - poor academic background and preparation for STEM subject matter, inefficient instructional approaches, and an absence of functional study habits and skills.
\end{abstract}

\section{Purpose}

The Center for Advanced Microwave and Research Applications (CAMRA), a NASAsponsored University Research Center (URC) is mandated to produce a significant number of students who obtain advanced degrees in STEM disciplines. In order to satisfy the requirements, CAMRA tests novel and innovative interventions that may potentially advance the designated outcomes.

During the summer 2005, CAMRA, through its summer bridge program, the PreAccelerated Curriculum in Engineering Program (PACE), hypothesized that a course on critical thinking could elevate information processing and, as a result, increase academic outcomes in STEM courses.

\section{Methods and Findings}

To test this theoretical perspective, PACE students participated in a five-week critical thinking course. This course met twice per week for 1.5 hours per class session for 15 weeks. Students were given the Watson Glaser Critical Thinking instrument as a pre- and postassessment to determine if the formal critical thinking course improved or enhanced students' critical thinking skills. Bloom's Taxonomy was used as a framework to help students differentiate between lower and higher order thinking skills.

Rather than using the traditional Grade Point Average (GPA) and Scholastic Assessment Test (SAT) scores as indicators to determine student success, exposing students to critical thinking instruction was used as an indictor to predict students' abilities to matriculate successfully through an engineering undergraduate program.

First t-tests for matched samples were applied to determine whether significant changes occurred in measured critical thinking skills as a result of participating in the PACE program in general and the PACE critical thinking course in general. While test scores did increase by .03 and .44 in two areas, a .389 decrease occurred in another area. However, the change in test scores were not significant $(\mathrm{P}<.22, .559$, and .4199 respectively).

However, the calculation of Pearson correlation coefficients revealed a significant correlation between critical thinking test scores and grades in the critical thinking class. This finding suggests that both the critical thinking class and the critical thinking standardized test measured similar cognitions. 
To further determine whether critical thinking skills have an independent relationship with academic outcomes, Pearson correlation coefficients were also calculated between critical thinking test scores or class grade and high school GPA or SAT scores. While most correlations were insignificant, critical thinking class grades were highly correlated with high school GPA. High School GPA also positively correlated with grades in other summer courses including computer science and physics. However, critical thinking scores were not correlated with grades in any of the summer courses. This suggests that more research is needed to determine whether students who already have strong critical thinking skills do well in a STEM curriculum.

\section{Conclusion}

Research is needed to determine whether a more intensive and extended training in critical thinking can elevate overall performance. While the key hypotheses could not be substantiated, the research demonstrates the need for STEM educators to apply different approaches in order to improve STEM outcomes by enhancing the information processing skills of STEM majors.

Key words: Critical Thinking; STEM Education and Minorities

\section{Introduction and Statement of the Problem}

Numerous initiatives, policies, and programs currently exist in recognition of the severity of the educational disparities that emerge in elementary school and culminate in the extreme under-representation of African Americans, Latinos, and Native Americans among doctoral candidates. A number of variables have been identified in the literature explaining, in part, one of the factors that contribute to the under-representation of minorities amongst students receiving doctorate degrees in STEM subjects.

\section{Academic Background and Preparation}

First, academic under-preparedness is a need that must be addressed in order to elevate minority representation amongst Ph.D. recipients. ${ }^{1}$ Differential efforts expended on students, discriminatory treatment, in combination with factors specific to the student, interact to produce academic under-preparedness. However, a number of factors correlate with academic background and preparation.

\section{Preparation in Schools and Differential Access to Knowledge}

Several studies have indicated that students of high socioeconomic status engage in more complex problem-solving and exercises in leadership development, thus learning how to be leaders, while their counterparts of low socioeconomic status do repetitive drills and learn how to be followers. Further, the school curriculum appears to benefit certain groups (white male students of high socioeconomic status) more than other groups (African-American students, female students, and students of low socioeconomic status). ${ }^{2}$ While minority children often begin school with positive attitudes toward the institution, differences in race, gender, and social class begin to emerge during elementary school and increase even more by high school, college, and graduate school. ${ }^{34}$ One investigator found that by $12^{\text {th }}$ grade, under-represented minority youth are reading and completing math exercises at the level of a Majority or Asian $8^{\text {th }}$ grader.

Class, racial, sexual, and even cultural discrimination influence the quality and quantity of material taught in schools, and therefore, begin the chain of under-preparedness that 
eventually restricts admission to a doctoral degree. Many low-income and minority youths, for example, attend overcrowded inner-city schools where the tax base is low and expenditures for education are lower. Moreover, public schools' expenditures per pupil are greatly influenced by the revenue received from federal, state, and local governments as well as revenue received from taxes. 5

The problem of financial inequity among educational institutions is complicated by other factors. Schools in the poorest districts have the double jeopardy of having students who are most at risk and the least amount of money to implement needed programs to improve the quality of education. Moreover, schools in some urban areas face additional costs because old buildings need constant repair and special security measures have to be implemented. Thus, the actual educational experiences per pupil are further reduced and preparation is hindered by differential access to academic resources.

\section{The Relationships Between Academic Under-preparedness of Multiple Risk Students and Administrative Decision-making}

Few social gatherings of middle-income parents occur without the recounting of horror stories regarding what has come to be called "tracking" (that is, placing students in groups according to perceived ability). The practice of tracking occurs widely at the primary and secondary levels, and colleges and universities indirectly apply it. Because administrators rely on test results that many view as culturally biased, together with the often subjective recommendations of teachers, certain demographic/ socioeconomic groups may be disproportionately placed in lower tracks. ${ }^{6}$ Thus, they enter college at greater risk.

For example, African-American, Latino and Native American students are disproportionately found in classes for lower-ability groups or track levels. Even high achieving minority students tend to be placed in low ability groups or non-college prep tracks, while lowachieving white, middle-class students tend to be placed in higher tracks or ability groups destined for college admission.

In some subject areas, deficiencies in preparation are difficult to repair. For example, early academic training is vital for the increased participation and performance of multiple-risk students in doctoral programs. Even more critical is that entry into a doctoral program is made almost exclusively through appropriate educational training. ${ }^{7}$ For example, mathematics, a sequential subject, should be introduced in an atmosphere that fosters positive attitudes in students, enabling them to benefit to the utmost from the learning experience. Yet, some teachers may transmit the attitude that achievement in mathematics is beyond the capability of multiplerisk students, thereby creating negative attitudes among those students. ${ }^{8}$

While concerted efforts have been made nationally to educate American youth in mathematics and the sciences, African Americans and other minority high school students continue to be underrepresented in academic programs and over-represented in vocational programs $^{9}$. An important implication of this distribution for educational achievement is that students in vocational education earn fewer school credits in areas such as English, Mathematics, and Science. Moreover, the content of their courses in those academic subjects is often different from that in other curricular tracks. For example, they may take general mathematics rather than algebra and trigonometry or general science rather than biology and chemistry ${ }^{10}$. Similar trends exist for women.

As one reviews the literature on academic background and preparation, it becomes clear that a number of systemic factors interact to create different degrees of academic under- 
preparedness among various demographic and socioeconomic groups. Even within the classroom, such practices continue to create under-preparedness.

\section{Teachers As a Resource and/or Barrier to Achievement}

Teachers may be a young person's most valuable resource after his/her parents. Indeed, many of a child's waking hours are spent with teachers. When a group of teenagers were asked "who or what influenced them to become the kinds of people they are, 58 percent mentioned one teacher or more, 90 percent mentioned their parents, and 88 percent mentioned peers"11. The evidence suggests, however, that teachers themselves may be a cause of academic underpreparedness and therefore of attrition and risk. For example, while 58 percent of students mentioned a teacher as a significant factor, the same students indicated that only 9 percent of all the teachers they had ever encountered in the course of their school careers had made a difference in their lives. That is, 91 percent of their teachers left non-memorable imprints.

These students indicated further that their classes were dull and boring and that school was one of the least favorite places they wished to be. Moreover, their favorite places in school were the cafeteria, the library, or the hallway ${ }^{12}$, thereby leading to dropout.

\section{Perceptions of the Value of Academic Achievements}

In general, the net present value of the degree is less for a minority than for a Majority male with a similar degree. Furthermore, the gap widens as the level of education increases. Minority students often observe such patterns first in their family and in their community. However, an empirical relationship between the lower returns to a doctoral training and minority enrollment levels has not yet been tested. However, many programs of STEM intervention do "market" the superior earnings that attenuate STEM occupations independent of race/ethnicity and gender. Thus, many very academically capable students may not develop positive attitudes toward a doctoral program.

This data are sometimes used to explain the fact that the leakage of minority students from the system at the graduate level is so profound that their retention rate is 50 to 75 percent lower than that of Majority students. The data are insufficient, however, to warrant the conclusion that educational institutions help to create unequal educational opportunity for all students.

Alternative explanations of the academic under-preparedness of minorities and other groups exist. Over recent years, arguments of innate inferiority have been supplanted by "value arguments." That is, some analysts now claim that minorities, in particular African Americans, do not value education. Research, however, does not support such arguments.

\section{Values Regarding Aspirations}

Some researchers have found that African American children have high occupational and educational aspirations and that they value academic achievement more highly than white or Mexican-American children ${ }^{13}$. Further, African American children report not only a greater desire than whites for a college education but also more encouragement from their parents to pursue a college degree. At the same time, however, African Americans consistently express expectations for success that contrast with their apparent values and aspirations. In other words, discrepancies occur between what they desire and what they expect to attain with regard to academic achievement ${ }^{14}$. 
Another area in which research is underdeveloped regarding minorities and the pursuit of higher education is in the area of information processing and cognitive development. It is necessary to provide a more in-depth discussion of theory and research in this area.

\section{The Relationship Between Information Processing and Cognitive Development: A Review of the Literature}

A special relationship exists between students' styles of processing information and their level of cognitive development. This relationship has particular relevance to the ability of multiple-risk students to eventually complete graduate school. Both information processing (i.e., how knowledge is organized in the mind and memory for later use) and cognitive development (i.e., how knowledge is carried and represented) are germane to the acquisition of the higherorder skills needed for graduate study ${ }^{15}$. The constructs of concrete reality and abstract concepts in the theory of information processing can be compared to the concrete and formal operations stages of Piagetian cognitive development theory. ${ }^{16}$

According to Piaget's hypothesis, the thought processes of children between the ages of about six and 12 to 14 operate on a concrete, holistic level and require a great deal of visualspatial stimulation. Piaget's next level of cognitive development, the formal operations stage, which children typically enter at about age 12 to 14 , is characterized by the ability for abstract and analytical thinking. ${ }^{17}$

The notion of holistic processing in the theory of information processing is characterized by a dependence on concrete reality (akin to Piaget's concrete operations stage). On the other hand, analytic or more abstract processing is characterized by reasoning ability and higher order thinking skills, similar to Piaget's formal operations stage of cognitive development ${ }^{18}$.

The literature reveals that some high school students never develop significantly beyond the concrete operations stage ${ }^{19}$. This case seems to be true for some multiple-risk students, many of whom fail to get the appropriate stimulation and learning experiences that would facilitate their advancement from the concrete to the more formal and analytic level of thinking and processing information that is needed for the completion of a doctoral program. ${ }^{20}$

Thus, multiple-risk students need exposure in the classroom to abstract and analytical reasoning processes to facilitate psycho-operational competencies. For example, it has been shown that instructional procedures emphasizing thinking aloud enabled students to construct hypothetical problems, analyze problems, and work through errors rather than avoid them ${ }^{21}$. Thinking aloud enables a student's performance to be critiqued and shaped by peers or instructors - a process that cannot be done effectively when the results are all that are available, instead of the thought processes that go into arriving at a solution ${ }^{22}$.

Such successful approaches to problem-solving are critical to the success of students who eventually enroll in a doctoral program. Prospective teachers in methods classes in teachers' education programs must be sensitized to the special relationships that exist between students' styles of processing information and their level of cognitive development. Those teachers who are already in the classroom must be given in-service training. Teachers must be aware of the value of classroom learning experiences and the role they play in helping students move from a concrete, holistic style of processing to a more abstract and analytic mode. ${ }^{23}$

\section{Differences in Styles of Processing Information}

Students' cognitive factors are related to the acquisition of information and the development of thinking skills. Thus, an understanding of how different students process 
information and the strategies they use to solve problems can provide insight into the programmatic interventions needed to advance multiple-risk students into a doctoral program. Those responsible for educating multiple-risk students must, therefore, understand how they develop intellectually.

The research suggests that students' "good" and "poor" performance in abstract conceptual skills may be linked to the development of abstract and concrete tendencies in processing information ${ }^{24}$. Piaget's cognitive development theory explains that abstract thinking is associated with formal operational thought, and, in turn, facilitates greater readiness for abstract concepts and complex problem-solving.

Minorities' style of processing information has been found to be more concrete and perceptually dependent (holistic) ${ }^{25}$. Moreover, the cognitive development of many of these students appears to be arrested at the concrete operations stage because their learning experiences may have failed to develop their analytic capabilities beyond routine levels ${ }^{26}$.

To compensate for this apparent preferential style of processing, some researchers have suggested that teachers use differential instructional approaches for students demonstrating predominance in holism so as to challenge and evoke responses from their preferred domain ${ }^{27}$. Such a suggestion has, however, the potential to systematically under challenge the analytic capabilities of those students ${ }^{28}$. A more useful approach may be to counter holistic, dependent tendencies with instructional approaches that help students overcome a dependency on a perceptually concrete learning mode and focus more on the formal operations consistent with their stage of cognitive development.

Theory of information processing asserts that the cognitive styles of students with more conceptually developed cognitive structures facilitate more reliance on formal and abstract reasoning for working out the hypothetical systematically and with less reliance on perception and concrete reality ${ }^{29}$. "Information processing styles" has been defined as a continuum of cognitive styles associated with right brain/left brain functions ${ }^{30}$. That is, each cognitive style represents two opposing extremes, such as impulsivity and reflectivity or field dependent and field independent ${ }^{31}$.

At the one extreme, impulsive individuals have a tendency to act spontaneously, giving the first answers that come to mind. At the other extreme, reflective individuals tend to take time to explore the plausible alternatives to respond to questions and resolve problems ${ }^{32}$. Field dependent individuals tend to depend on global perception and demonstrate a need for an "inordinate" amount of concrete referents to work through problems (actual objects, pictures, graphs, diagram, and so on $)^{33}$. Further, they tend to be holistic and focus on the total environment, giving credit to external references and taking other people's views into account. Conversely, field-independent persons tend to rely on internal referents in a self-consistent way. Thus, they can quickly and efficiently extract important information from distracting influences ${ }^{34}$. Field independence has been associated with many cognitive problem-solving skills necessary for manipulating and restructuring the world through symbolic thought processes. Moreover, these problem-solving skills correlate with existing instructional styles.

Field-dependent students could be at a disadvantage in a doctoral program. They would, for example, need more visual or oral instructions in solving problems, as well as a greater definition of performance outcomes than field-independent students. Moreover, relatively fielddependent students are not likely to do as well in mathematics and science as more fieldindependent students, given the way these disciplines are taught ${ }^{35}$. 
It has been argued that women and some racial minorities also think less analytically than Majority males and that this cognitive pattern is responsible for their lower academic performance in mathematics and science. Such analysts also assert that females and most racial minorities develop a more global and less analytical mode of processing information. Others have challenged these conclusions ${ }^{36}$. Perhaps the instrumentation used for measuring the analytic mode, rather than the type of thinking itself, is a major factor in the observed differences.

A paradigm of information processing, based on some groups' having developed a special cultural pattern and a specific method for organizing and processing information, illustrates the way that African Americans and other underrepresented minority students perceive, encode, represent, and analyze information ${ }^{37}$. While the preferred modality for receiving information in the American culture is visual, the emphasis among African-Americans' cue selection may also be different from that used by the Majority culture ${ }^{38}$. (The selection of cues is important for encoding and representing information that will be retained from the barrage of information to which one is exposed). Because, as the literature suggests, African Americans are socialized to be person-oriented rather than object/thing-oriented ${ }^{39}$, their cueselection preferences tend to be people and events rather than ideas and objects. Contemporary instructional techniques, however, are based upon ideas and objects.

Minorities and women's orientation toward people may be the result of the interaction between a variety of cultural and personal forces and the physical environment. It is the orientation that can create a value orientation focused on people, which in turn predisposes them to careers in the education and social sciences when doctoral studies are pursued and away from the natural and physical sciences and engineering.

Like the processing styles of impulsivity and reflectivity, however, field dependence and field independence are not mutually exclusive within anyone person and should therefore not be considered as absolute dichotomy ${ }^{40}$. Further, mutualism between the processing systems provides the individual with an increased level of intellectual strength ${ }^{41}$. This point of view should provide the impetus for change for those who advocate holism as a fixed mode of learning to the exclusion of learning experiences in the classroom.

Thus, an important question is raised: Is holistic perception characteristic of minorities and women, or is holism tied to the lack of stimulation of latent analytic capabilities in these students?

\section{The Effect of Information-Processing Styles on Learning for Multiple-risk Students}

Psycho educational studies agree that preferences of modality associated with holism in processing behavior should not be treated as "inferior" ${ }^{24}$. Instead, this processing style should be complemented with classroom and other learning experiences designed to challenge and stimulate more analytic thinking skills. Most research on modality preferences of people of African heritage to date has failed to go beyond affective characteristics and patterns of socialization, thus providing an incomplete assessment of the functioning of their intellect ${ }^{44}$.

In contrast to the numerous studies that report holism in African-Americans and other multiple-risk groups, empirical evidence suggests analytical tendencies among some AfricanAmerican students. Studies with African-American students, however, support the conclusions of previously research on differences in achievement between students who demonstrate an abstract learning style and those who are concrete learners. That is, African American students who had a reflective processing style and engaged in abstract reasoning earned higher grades than their counter-parts who were classified as concrete learners ${ }^{45}$. Indeed, African-American 
students who are high achievers in mathematics were found to have profiles similar to higher achieving students of other ethnic groups on important variables, such as problem-solving, achievement in reading, IQ, socio-economic status, achievement in mathematics, and mathematics self-concept.

Another class study attempted to identify relationships among mode of processing behavior, level of cognitive development, and achievement in mathematics in a sample of urban African-American high school students ${ }^{46}$. Only a modest amount of holism was found in the sample (32 percent), compared to what would be expected given the preponderance of literature that labels African-Americans as holistic. Just under half (46 percent) of the students used an integrated mode of processing behavior. Almost one-fourth of the sample (22 percent) were analytic, and they had higher scores in mathematics than both the integrated and the holistic students ${ }^{47}$, underscoring the current literature that analysis processing behavior is hierarchically more germane to minority achievement than holism, particularly in mathematics and science.

It cannot be emphasized enough that holism should not be treated as inherent in AfricanAmericans to other multiple-risk students, because doing so would provide a rationale for systematically under-challenging these students. Students who were taught by teachers who emphasized abstract reasoning have higher mean scores on national norm-referenced measures than students who were taught by teachers who focused on computation ${ }^{48}$.

\section{Purpose of this Study}

While a lively debate has ensued over the last 20 years regarding the information processing and cognitive development styles of under-represented minorities, few efforts have been implemented which seek to systematically strengthen the information-processing skills and cognitive styles of minority undergraduates. The purpose of this study was that of determining whether a Critical Thinking course can be used as a tool for enhancing the information processing skills of students who have declared STEM majors.

\section{Methods}

Research Questions

In order to achieve such an outcome, however, the Critical Thinking course must first correlate with significant areas in standardized critical thinking test scores. Thus, the study sought to assess the change in critical thinking test scores after exposure to a critical thinking course by answering the question "Was there a significant increase in critical thinking test scores?" Second, it was necessary to validate the fact that the assessment of the student's critical thinking class performance was significantly correlated with the independent measure of critical thinking skills using reliable and valid standardized instrumentation. The study therefore answers a secondary research question, "Is there a relationship between critical thinking test scores as measured by a standardized instrument, and grades in the Critical Thinking class?" Stated differently, was the test and the grading process responsive to a common set of information processing skills?

Third, the study was designed to determine whether, as hypothesized in the literature, higher-level information processing skills are directly related to academic performance as measured by high school GPA or SAT scores.

The study used critical thinking scores as a proxy measure of higher-level information processing and overall cognitive skills. Thus, the study sought to determine whether a relationship existed between critical thinking skills and grades in Physics and Chemistry and 
Computer Science. Finally, again, consistent with conceptual and theoretical literature, the study examined differences in critical thinking test scores by gender, and other factors.

\section{$\underline{\text { Data Collection }}$}

Morgan State University School of Engineering is a site for the NASA funded Center of Advanced Microwave Research and Application (CAMRA), a NASA University Research Center (URC). CAMRA is in its fourth year of operation as a research service-oriented URC, which conducts and produces, NASA-related research that will aid in future NASA missions. The overall mission of CAMRA consists of two major goals:

1. To provide NASA's future Science and Exploration missions with a technology base for the production of microwave components and systems such as RFIC's (amplifiers, mixers, LO's) and low power digital logic; and

2. To produce a significant and proficient pool of Science, Technology, Engineering, and Mathematics (STEM) professionals with advanced applied degrees in Engineering (M. Eng. and D. Eng.).

CAMRA continues to work towards accomplishing its goals through its executive officers, technical research centers and through its service center - Academic Training Career Management office (ATMO).

One of the programs operated by CAMRA is the PACE program, a pipeline program that works in conjunction with CAMRA to admit students who will ultimately complete doctorate degrees in engineering through the CAMRA program. A Critical Thinking instrument was administered to $100 \%$ of PACE's 17-22 summer program participants at the beginning and end of the summer program. This instrument measured each participant's inferential skills, skills in recognition assumptions, deductive skills, interpretative skills, and the participant's ability to evaluate an argument. The survey was also administered at the end of the summer program.

A specialized Critical Thinking course was designed and implemented during the Summer, 2005. The Critical Thinking course was assessed before full implementation for interrater reliability. Data on performance were obtained by requesting that each PACE program participant and their parents sign consent forms that allowed their data to be used for research purposes.

\section{Data Analysis}

Two methods of data analysis were used. In order to determine whether a significant increase in critical thinking test scores occurred, t-tests were used. In order to measure whether a relationship exists between the other key variables, Pearson Correlation coefficients were calculated. Despite the simplicity of these techniques, these analytical techniques were appropriate to the research questions.

\section{Findings}

Table I below presents the results of the t-tests that were calculated in response to the Research Question \#1: Was there a significant increase in critical thinking standardized test scores as a result of a systematic effort to improve the information processing skills of the student? 


\begin{tabular}{|l|r|r|r|}
\hline \multicolumn{4}{|c|}{$\begin{array}{l}\text { Table 1: Mean Pre/Post Critical Thinking Scores By } \\
\text { Information Processing Area }\end{array}$} \\
\hline & \multicolumn{1}{|c|}{ Means } & N & \multicolumn{1}{l|}{$\begin{array}{l}\text { Std. } \\
\text { Deviation }\end{array}$} \\
\hline Pair 1: & 5.631 & 19 & 1.64 \\
Pre-Inference Score & 5.636 & 22 & 1.81 \\
Post-Inference Score & & & \\
\hline Pair 2: & 7.473 & 19 & 3.00 \\
Pre: Recognition of Assumption & 9.476 & 21 & 2.00 \\
Post: Recognition of Assumption & & & \\
\hline Pair 3: & 7.842 & 19 & 1.641 \\
Pre: Deductive Skills & 8.818 & 22 & 2.630 \\
Post: Deductive Skills & & & \\
\hline Pair 4: & 10.368 & 19 & 2.191 \\
Pre: Interpretative Skills & 10.045 & 22 & 2.126 \\
Post: Interpretative Skills & & & \\
\hline Pair 5: & 8.157 & 19 & 2.522 \\
Pre: Ability to Evaluate an Argument & 9.045 & 22 & 2.192 \\
Post: Ability to Evaluate an Argument & & & \\
\hline
\end{tabular}

As Table I indicates, participation in the Critical Thinking course did generate an improvement in the mean information processing skills of the participants in all functional areas except interpretation. An actual decrease in mean score occurred in this area. Table 2 below provides additional information regarding the lower and upper values for the 95 percent confidence interval of the differences in the pre- and post-tests. 


\begin{tabular}{|l|c|c|c|c|c|r|r|r|}
\hline \multicolumn{7}{|c|}{ Table 2: The T-Test Procedures Statistics } \\
\hline & $\mathrm{N}$ & $\begin{array}{l}\text { Lower } \\
\text { CL } \\
\text { Mean }\end{array}$ & Mean & $\begin{array}{l}\text { Upper } \\
\text { CL } \\
\text { Mean }\end{array}$ & $\begin{array}{l}\text { Lower CL } \\
\text { Standard } \\
\text { Deviation }\end{array}$ & $\begin{array}{l}\text { Standard } \\
\text { Deviation }\end{array}$ & $\begin{array}{l}\text { Upper } \\
\text { CL } \\
\text { Standard } \\
\text { Deviation }\end{array}$ & $\begin{array}{l}\text { Standard } \\
\text { Error }\end{array}$ \\
\hline $\begin{array}{l}\text { Post-test \& } \\
\text { Pre-test } \\
\text { Interpretation }\end{array}$ & 18 & -1.766 & 0.389 & 0.9877 & 2.0773 & 2.7683 & 4.1501 & 0.6525 \\
\hline $\begin{array}{l}\text { Post-test \& } \\
\begin{array}{l}\text { Pre-Test } \\
\text { Assumption- }\end{array}\end{array}$ & 17 & -0.215 & 1.5294 & 3.2741 & 2.5273 & 3.3933 & 5.1644 & 0.823 \\
\hline $\begin{array}{l}\text { Post-test \& } \\
\text { Pre-Test } \\
\text { Deductive }\end{array}$ & 18 & -0.565 & 0.8333 & 2.2321 & 2.1107 & 2.8128 & 4.2168 & 0.663 \\
\hline $\begin{array}{l}\text { Post-Test \& } \\
\text { Pre-Test } \\
\text { Evaluation }\end{array}$ & 18 & 0.69 & 0.4444 & 1.5787 & 1.7116 & 2.2809 & 3.4194 & 0.5376 \\
\hline $\begin{array}{l}\text { Post-Test \& } \\
\text { Pre- Test } \\
\text { Inference }\end{array}$ & 18 & -0.806 & 0.1111 & 1.0279 & 1.3834 & 1.8436 & 2.7638 & 0.4345 \\
\hline
\end{tabular}

Table 3 below provides the results of the t-tests on the pre- and post-test differences. As Table 3 indicates, while positive changes occurred in the information processing skills of the participants, the changes were not significant. Only the areas-recognition of assumptions experienced a marginally significant change with a $\mathrm{P}<.08$.

\begin{tabular}{|l|l|l|l|}
\hline \multicolumn{4}{|c|}{ Table 3: Differences on the Pre/Post-Tests } \\
\hline Difference & DF & T Value & Pr $>$ t \\
\hline Post-test int & 17 & -0.60 & 0.5590 \\
\hline Pot-test assumption & 16 & 1.86 & 0.0816 \\
\hline Post-test deduction & 17 & 1.26 & 0.2258 \\
\hline Post--test evaluation & 17 & 0.83 & 0.4199 \\
\hline Post-test inf & 17 & 0.26 & 0.8012 \\
\hline
\end{tabular}

Despite the insignificance of the change in information processing skills, the findings suggest that with greater intensity of effort, it may be possible to effect greater change. However, before an expanded intervention is implemented to use critical thinking courses to augment the information processing skills of underserved minority STEM majors, it is necessary to confirm that the course content and the critical thinking standardized test are, indeed, assessing common skills. If so, critical thinking test scores and grades in the Critical Thinking courses should be significantly correlated. Thus, correlation coefficients were calculated in order to answer the question, :Is there a relationship between critical thinking test scores and grades in the critical thinking course. 
As Table 4 below indicates, greater congruency is needed between the skills covered in the class and those measured by the standardized Critical Thinking tests. Inferential skills covered in the class apparently matched those covered in the test $(\mathrm{P}<.0076)$. Despite the decrease in interpretation skills, there was a significant correlation between class grades and standardized test results $(\mathrm{P}<.0051)$. A marginally significant relationship occurred between the class's assessment of critical thinking skills in the area of Evaluation of Argument $(\mathrm{P}<.0981)$. However, the other areas require additional alignment.

\begin{tabular}{|l|r|r|r|}
\hline \multicolumn{4}{|c|}{ Table 4: Differences Between Class Skills and Critical Thinking } \\
& \multicolumn{1}{|c|}{$\begin{array}{l}\text { Tests } \\
\text { Critical } \\
\text { Thinking }\end{array}$} & $\begin{array}{l}\text { Mean } \\
\text { Score }\end{array}$ & $\begin{array}{l}\text { \# of } \\
\text { Students }\end{array}$ \\
\hline Thinking Skills & 1.00000 & & 24 \\
\hline Pre-Test Inferential Skills & -0.02494 & 0.9193 & 19 \\
\hline Post-Test Inferential Skills & 0.55286 & 0.0076 & 22 \\
\hline Pre-Test Assumption & -0.11095 & 0.6511 & 19 \\
\hline Post-Test Assumption & 0.12474 & 0.5901 & 21 \\
\hline Pre-Test Deduction Skills & -0.19319 & 0.4281 & $\ldots .19$ \\
\hline Post-Test Deduction Skills & 0.12970 & 0.5651 & 22 \\
\hline $\begin{array}{l}\text { Pre-Test Interpretation } \\
\text { Skills }\end{array}$ & 0.20468 & 0.4006 & 19 \\
\hline $\begin{array}{l}\text { Post-Test Interpretation } \\
\text { Skills }\end{array}$ & 0.57492 & 0.0051 & 22 \\
\hline Pre-Test Evaluation Skills & 0.39075 & 0.0981 & $\ldots . . .19$ \\
\hline $\begin{array}{l}\text { Post-Test Evaluation } \\
\text { Skills }\end{array}$ & 0.03518 & 0.8765 & 22 \\
\hline
\end{tabular}

Students who use higher level thinking skills as measured by their Critical Thinking Test Scores should also have higher high school GPAs and/or higher SAT tests. The data were, therefore, analyzed to answer the question, "Is there a relationship between critical thinking scores and mean high school GPA, and/or SAT score?

\begin{tabular}{|c|c|c|c|c|}
\hline \multicolumn{5}{|c|}{$\begin{array}{c}\text { Table 5: Relationship Between Critical Thinking Scores and Mean } \\
\text { High School GPA and/or SAT Scores }\end{array}$} \\
\hline & Verbal & Math & Total & Mean \\
\hline $\begin{array}{l}\text { Post-test } \\
\text { Inferential Score }\end{array}$ & 0.31012 & 0.11857 & 0.23504 & 0.29458 \\
\hline $\mathrm{P}$ & 0.1833 & 0.6186 & 0.3185 & 0.1949 \\
\hline
\end{tabular}




\begin{tabular}{|c|c|c|c|c|}
\hline \multicolumn{5}{|c|}{$\begin{array}{c}\text { Table 5: Relationship Between Critical Thinking Scores and Mean } \\
\text { High School GPA and/or SAT Scores }\end{array}$} \\
\hline & Verbal & Math & Total & Mean \\
\hline $\mathrm{N}$ & 20 & 20 & 20. & 21 \\
\hline $\begin{array}{l}\text { Pre-test } \\
\text { Inferential Score }\end{array}$ & 0.47739 & 0.26781 & 0.41509 & -0.12314 \\
\hline$\dddot{\mathrm{P}}$ & 0.0526 & 0.2987 & 0.0976 & 0.6264 \\
\hline $\mathrm{N}$ & 17 & 17 & 17 & 18 \\
\hline $\begin{array}{l}\text { Post-test } \\
\text { Assumption } \\
\text { Score }\end{array}$ & -0.17690 & 0.06601 & -0.05216 & 0.01505 \\
\hline $\mathrm{P}$ & 0.4556 & 0.7822 & 0.8271 & 0.9484 \\
\hline $\mathrm{N}^{-}$ & 20 & 20 & 20 & 21 \\
\hline $\begin{array}{l}\text { Pre-test } \\
\text { Assumption } \\
\text { Score }\end{array}$ & 0.32444 & 0.17587 & 0.27830 & -0.17379 \\
\hline $\mathrm{P}$ & 0.2039 & 0.4996 & 0.2794 & 0.4904 \\
\hline $\mathrm{N}$ & 17 & 17 & 17 & 18 \\
\hline $\begin{array}{l}\text { Pre-test } \\
\text { Deduction Score }\end{array}$ & 0.11540 & 0.10367 & 0.12440 & -0.15638 \\
\hline $\mathrm{P}$ & 0.6592 & 0.6921 & 0.6343 & 0.5355 \\
\hline $\mathrm{N}$ & 17 & 17 & 17 & 18 \\
\hline $\begin{array}{l}\text { Post-test } \\
\text { Deduction Score }\end{array}$ & 0.27062 & -0.17038 & 0.03727 & 0.08777 \\
\hline $\mathrm{P}$ & 0.2485 & 0.4726 & 0.8760 & 0.7052 \\
\hline $\mathrm{N}^{-}$ & 20 & 20 & 20 & 21 \\
\hline $\begin{array}{l}\text { Pre-test } \\
\text { Interpretation } \\
\text { Score }\end{array}$ & -0.11373 & -0.17480 & -0.16748 & 0.35299 \\
\hline P & 0.6638 & 0.5022 & 0.5205 & 0.1508 \\
\hline $\mathrm{N}$ & 17 & 17 & 17 & 18 \\
\hline $\begin{array}{l}\text { Post-test } \\
\text { Interpretation } \\
\text { Score }\end{array}$ & -0.12836 & 0.20365 & 0.05761 & 0.26741 \\
\hline $\mathrm{P}$ & 0.5897 & 0.3891 & 0.8094 & 0.2412 \\
\hline $\mathrm{N}$ & 20 & 20 & 20 & 21 \\
\hline $\begin{array}{l}\text { Pre-test } \\
\text { Evaluation Score }\end{array}$ & 0.18536 & 0.06682 & 0.13820 & 0.55322 \\
\hline P & 0.4763 & 0.7989 & 0.5968 & 0.0172 \\
\hline $\mathrm{N}$ & 17 & 17 & 17 & 18 \\
\hline $\begin{array}{l}\text { Post-test } \\
\text { Evaluation Score }\end{array}$ & 0.04900 & -0.09589 & -0.03311 & -0.20228 \\
\hline $\mathrm{P}$ & 0.8375 & 0.6876 & 0.8898 & 0.3792 \\
\hline $\mathrm{N}$ & 20 & 20 & 20 & 21 \\
\hline Critical Thinking & 0.08761 & 0.23077 & 0.18688 & 0.70506 \\
\hline
\end{tabular}




\begin{tabular}{|c|c|c|c|c|}
\hline \multicolumn{5}{|c|}{$\begin{array}{c}\text { Table 5: Relationship Between Critical Thinking Scores and Mean } \\
\text { High School GPA and/or SAT Scores }\end{array}$} \\
\hline & Verbal & Math & Total & Mean \\
\hline $\mathrm{P}$ & 0.6982 & 0.3015 & 0.4050 & 0.0002 \\
\hline $\mathrm{N}$ & 22 & 22 & 22 & 23 \\
\hline
\end{tabular}

Several researchers have discovered that for minority students, GPA is a greater predictor of academic success than are SAT or Graduate Record Examinations (GRE) scores. This trend appears to hold true in this study. While no significant relationship existed the measured superior information processing skills and SAT performance, a direct and significant relationship existed between critical thinking scores and high school performance $(\mathrm{P}<.0002)$. Thus, underrepresented minority students who do have higher level information processing skills also have higher grades upon entry into a four-year STEM program. While the participant's first year academic performance has not yet been integrated into the study, the implications of these findings are quite compelling. That is, if a highly effective critical thinking component is used with minority STEM majors, it may be possible to equip them with the higher level skills associated with success in a STEM program.

When the data were analyzed, however, to determine whether a positive and significant correlation existed between measured critical thinking scores on the standardized tests, and the students' performance in STEM courses during the summer, the relationship vanished. Table 6 below answers the question, "Were Critical Thinking scores correlated with STEM grades in the summer courses? 


\begin{tabular}{|c|c|c|c|c|}
\hline \multicolumn{5}{|c|}{$\begin{array}{l}\text { Table 6: Relationship Between Critical Thinking Scores and STEM } \\
\text { Grades in Summer Courses }\end{array}$} \\
\hline & Physics & Chemistry & English & Science \\
\hline $\begin{array}{l}\text { Post-Test Inferential } \\
\text { P } \\
\text { N }\end{array}$ & $\begin{array}{l}0.29779 \\
0.1783 \\
22\end{array}$ & $\begin{array}{l}0.14421 \\
0.5328 \\
21\end{array}$ & $\begin{array}{l}0.32090 \\
0.1454 \\
22\end{array}$ & $\begin{array}{l}-0.03898 \\
0.8633 \\
22\end{array}$ \\
\hline Pre-Test Inferential & $\begin{array}{l}-0.09430 \\
0.7010 \\
19\end{array}$ & $\begin{array}{l}-0.03619 \\
0.8866 \\
18\end{array}$ & $\begin{array}{l}-0.07043 \\
0.7745 \\
19\end{array}$ & $\begin{array}{l}-0.17459 \\
0.4747 \\
19\end{array}$ \\
\hline $\begin{array}{l}\text { POST-Test Assumption } \\
\text { P } \\
\mathrm{N}\end{array}$ & $\begin{array}{l}0.45716 \\
0.0372 \\
21\end{array}$ & $\begin{array}{l}0.17443 \\
0.4495 \\
21\end{array}$ & $\begin{array}{l}0.33118 \\
0.1425 \\
21\end{array}$ & $\begin{array}{l}0.17531 \\
0.4472 \\
21\end{array}$ \\
\hline $\begin{array}{l}\text { PRE-Test Assumption } \\
\text { P } \\
\mathrm{N}\end{array}$ & $\begin{array}{l}-0.14511 \\
0.5534 \\
19\end{array}$ & $\begin{array}{l}0.07870 \\
0.7563 \\
18\end{array}$ & $\begin{array}{l}0.33081 \\
0.1665 \\
19\end{array}$ & $\begin{array}{l}-0.28618 \\
0.2349 \\
19\end{array}$ \\
\hline $\begin{array}{l}\text { PRE-Test Deduction } \\
\text { P } \\
\mathrm{N}\end{array}$ & $\begin{array}{l}-0.22861 \\
0.3465 \\
19\end{array}$ & $\begin{array}{l}-0.34504 \\
0.1608 \\
18\end{array}$ & $\begin{array}{l}0.27930 \\
0.2469 \\
19\end{array}$ & $\begin{array}{l}-0.13097 \\
0.5930 \\
19\end{array}$ \\
\hline $\begin{array}{l}\text { Post-Test Deduction } \\
\text { P } \\
\text { N }\end{array}$ & $\begin{array}{l}0.03056 \\
0.8926 \\
22\end{array}$ & $\begin{array}{l}0.06724 \\
0.7721 \\
2 i\end{array}$ & $\begin{array}{l}0.14753 \\
0.5123 \\
22\end{array}$ & $\begin{array}{l}0.00330 \\
0.9884 \\
22\end{array}$ \\
\hline $\begin{array}{l}\text { Pre-Test Interpretation } \\
\mathrm{P} \\
\mathrm{N}\end{array}$ & $\begin{array}{l}0.32230 \\
0.1784 \\
19\end{array}$ & $\begin{array}{l}0.02805 \\
0.9120 \\
18\end{array}$ & $\begin{array}{l}-0.34554 \\
0.1473 \\
19\end{array}$ & $\begin{array}{l}0.27493 \\
0.2546 \\
19\end{array}$ \\
\hline $\begin{array}{l}\text { Post-Test Interpretation } \\
\mathrm{P} \\
\mathrm{N}\end{array}$ & $\begin{array}{l}0.39392 \\
0.0697 \\
22\end{array}$ & $\begin{array}{l}0.40148 \\
0.0712 \\
21\end{array}$ & $\begin{array}{l}0.33760 \\
0.1244 \\
22\end{array}$ & $\begin{array}{l}0.19479 \\
0.3850 \\
22\end{array}$ \\
\hline $\begin{array}{l}\text { Pre-Test Evaluation } \\
\text { P } \\
\mathrm{N}\end{array}$ & $\begin{array}{l}0.35054 \\
0.1412 \\
19\end{array}$ & $\begin{array}{l}0.41536 \\
0.0865 \\
18\end{array}$ & $\begin{array}{l}-0.06125 \\
0.8033 \\
19\end{array}$ & $\begin{array}{l}0.00625 \\
0.9797 \\
19\end{array}$ \\
\hline $\begin{array}{l}\text { Post-Test Evaluation } \\
\text { P } \\
\mathrm{N}\end{array}$ & $\begin{array}{l}-0.04164 \\
0.8540 \\
22\end{array}$ & $\begin{array}{l}0.20349 \\
0.3763 \\
2 i^{3}\end{array}$ & $\begin{array}{l}0.12831 \\
0.5693 \\
22\end{array}$ & $\begin{array}{l}-0.15578 \\
0.4888 \\
22\end{array}$ \\
\hline
\end{tabular}

That is, there was no significant correlation between the students measured critical thinking skills and their subsequent performance in STEM courses. However, the failure of the intervention to achieve significance in this area does not suggest programmatic failure. Rather, it recommends increasing the dosage of the intervention and completing additional tests of the efficacy of the interventions. A mere 15 hours of exposure to critical thinking cannot successfully reverse lifetime information-processing approaches.

Given that the literature confirms differences in higher level thinking skills by gender, the data were analyzed to determine whether these trends were observable in this study. Students with higher order thinking skills are, according to the literature, more likely to perform well in mathematics. Thus, the data were analyzed to determine whether a relationship existed between fall and summer math placement and measured critical thinking test scores.

Several patterns prevailed:

$>$ Females scored higher than males on the post-test in the area of Evaluation of Arguments; 
Students in lower levels of fall MSU math classes did score lower in the critical thinking standardized test.

However, these differences in information processing and learning style did not reveal themselves in the summer month placement.

\section{Discussion}

Taken together, this heuristic study is highly instructive. It suggests the need of further research on the efficacy of using formalized electronic or in-class Critical Thinking courses to bring the information processing and cognitive skills of under-represented STEM majors into greater congruency with those learning styles associated with success in STEM courses. However, the study is highly significant given the paucity of interventions in this area.

\section{Limitations of the Study}

This analysis is purely exploratory. The small size of the sample limited the analysis to bivariate statistics. Additionally, the large number of statistical tests conducted makes it likely that many of the findings are due to chance. Hence, a p-value of 0.01 was used instead of 0.05 on all tests except the paired sample t-tests. Lastly, the correlation analyses do not allow causal conclusions.

Nevertheless, as mentioned, the research opens up a new area of empirical inquiry that complements the abundance of theory in this area.

\section{Summary}

Morgan State University has served as an innovator in the area of STEM research and practice and under-represented minorities for nearly two decades. This research effort is consistent with this trend.

\section{End Notes}

\footnotetext{
${ }^{1}$ Payton, Fay Cobb, "Making STEM Careers More Accessible,” Black Issues in Higher Education, 2004-03-11, V. 21, 112, P90, March 2004.

${ }^{2}$ Reyes, L.H. and G.M.A. Stanic, 1985. “A Review of Literature on Blacks and Mathematics,” Paper presented at an annual meeting of the American Educational Research Association, April, Chicago, Illinois.

${ }^{3}$ Beane, D.B. 1985. Mathematics and Science: Critical Filters for the Future of Minority Students. Washington

D.C.: American University, Mid-Atlantic Center for Race Equality.

${ }^{4}$ See National Coalition 1985 for a more complete discussion of the effects of discrimination and differential treatment in children.

${ }^{5}$ Societal Support for Learning: Public Financial Support. National Center for Education Statistics. 1999. See http://nces.ed.gov/programs/coe/2002/section6/indicators43.asp.

${ }^{6}$ Raze, N. 1984. "Overview of Research on Ability Grouping." Redwood City, Cal. San Mateo County, Office of Education. EO252 927.11, pp. MF-01; pc-01.

${ }^{7}$ Keels Crystal L., "Bridging the Cap: National Science Foundation Initiative Eases the Transition from Undergraduate to Graduate Study," Black Issues in Higher Education, Vol. 1, N12, p 30, July, 2004.

${ }^{8}$ Warren John and Hytten Kathy, "The Faces of Whiteness: Pitfalls and the Critical Democrat," Communication Education, 2004-10-00, V53, N4, P321-339, Oct. 2004.
} 
${ }^{9}$ Bailey Thomski; Matsuzaka Yukari; Jacobs James; Merest Vanessa; Hughes Katherine. "Institutionalization and Sustainability of the National Science Foundation's Advanced Technological Education Program. CCRC Brief. November 20, 2004-03-00.

10 ibid.

${ }^{11}$ American Association for the Advancement of Science, 1994. Equity and Excellence: Compatible Goals. Washington, D.C., Office of Opportunities in Science.

${ }^{12}$ Ibid.

${ }^{13}$ Banks, McQuater, and Hubbard 1978, op. cit.

${ }^{14}$ ibid.

${ }^{15}$ Klausmeier, H., and Associates. !979. Cognitive Learning and Development: Piagetian and Information Processes. and Perspectives. Cambridge, Mass.

${ }^{16}$ DeBello TC (1990). "Comparison of Eleven Major Learning Style Models: Variables, Appropriate Populations, Validity of Instrumentation, and the Research Behind Them," Reading, Writing, and Learning Disabilities, 6, 203222.

${ }^{17}$ Dunn R and Dunn K (1993). Teaching Secondary Learning Styles: Practical Approaches Grades 7-12 (p. 39) (Boston, MA: Allyn and Bacon.

${ }^{18}$ Wagner, S. 1977. "Conservation of Equation and Functioning and its Relationship to Formal Operational thought. Paper presented on annual meeting of the American Educational Research Association, April 4-8, New York, N.Y. pp. 114-117. MF-01; pc-02.

${ }^{19}$ Ibid.

${ }^{20}$ Dunn R, Bruno J, Sklar RI, Beaudry J (1990). Effects of Matching and Mismatching Minority Development College Students Hemispheric Differences on Mathematics Scores," Journal of Educational Research, 83(5), 22828.

${ }^{21}$ Resnick, G.P. and B. Resnick. 1985. Standards, Curriculum, and Performance: A Historical and Comparative Perspective. Educational Researcher 14(47:5-21).

22 ibid.

${ }^{23}$ Felder RM; Silverman LK (1988). “Learning and Teaching Styles in Engineering Education.” Engineering Education, 78(2), 674-681.

${ }^{24}$ Klausmeier, H. and Associates. 1979. Cognitive Learning and Development. Piaget and Information Processing Perspective. Cambridge: Mass.

${ }^{25}$ Shade 1984, op. cit.

${ }^{26}$ Gordon RB (1993). "The Effects of Computerized Instruction on the Improvement and Transfer of Writing Skills for Low-Skilled and Below Average-Skilled, and Below-Average Skilled Sophomores Students, Considering Student Gender, Ethnicity, and Learning Style Reference. (Doctoral Dissertation, University of LaVerne, Dissertation Abstracts International, 455(1), 23.

${ }^{27}$ Olstad, A., J. Juarez, L. Davenport, and D. Harry. 1981. Inhibitors to Achievement in Science and Mathematics by Ethnic Minorities. ED223 404. 136 pp. MF-01: pc-06

${ }^{28}$ Herrick B; Bodny D; Samples J (1998). "Teaching to Your Audience." Proceedings of the Frontiers in Education Conference, Sessnios T1H, Tempe, AZ.

${ }^{29}$ Witkin, H.A. and D.R. Goodenough, and P.W. Cox. 1997. "Field Dependent and Field Independent Cognitive Styles and Their Educational Implications." Review of Education Research 47(1):1-64.

${ }^{30}$ Fennema and Behr, op. cit.

31 ibid.

32 ibid.

${ }^{33}$ ibid.

${ }^{34}$ Witkin et. al. 1977 , op. cit.

${ }^{35}$ Larkin TV. (2003). "Learning Style in the Classroom: A Research-Guided Approach," Proceedings of the International Conference in Engineering and Computer Education. (ICECE 2003, Session ET1B), Santo, Brazil.

${ }^{36}$ Roberts, Veronica A. 1989. "An Evaluation of Secondary School Mathematics: Relationship Among Processing Behavior Mode, Cognitive Development Level and Mathematics Achievement in Black, Metropolitan High School Students." Ph.D. Dissertation, Howard University.

${ }^{37}$ Shade 1984. op. cit.

${ }^{38}$ ibid.

${ }^{39}$ ibid.

${ }^{40}$ Witkin and Goodenough 1981, op. cit. 
${ }^{41}$ Kaufman , G. 1979. Visual Imagery and Its Relations to Problem-Solving. New York: Columbia University Press.

${ }^{42}$ ibid.

${ }^{43}$ Roberts 1990. op. cit.

${ }^{44}$ Madhere 1989, op. cit.

${ }^{45}$ Vance and Engin 1978, op. cit.

${ }^{46}$ Roberts 1990, op. cit.

${ }^{47}$ ibid.

${ }^{48}$ ibid. 